\title{
Effect of the pandemic on the Distribuidora Los Paisas, through the study of leverage and activity
}

\section{Efecto de la pandemia en la Distribuidora Los Paisas, a través del estudio del apalancamiento y la actividad}

\author{
TUAREZ-SOLORZANO, Diana Elizabeth ${ }^{*} *$ TRIANA-JIMENEZ, Katherin Yessenia and \\ GUTIERREZ-JARAMILLO, Daniel Néstor
}

Universidad Técnica de Machala, Ecuador.

ID 1 ${ }^{\text {st }}$ Author: Diana Elizabeth, Tuarez-Solorzano / ORC ID: 0000-0003-2455-844X

ID $1^{\text {st }}$ Co-author: Katherin Yessenia, Triana-Jimenez / ORC ID: 0000-0001-9422-8943

ID $2^{\text {nd }}$ Co-author: Daniel Néstor, Guitierrez-Jaramillo / ORC ID: 0000-0001-9487-6342

DOI: $10.35429 / J A F .2021 .22 .8 .1 .8$

Received January 10, 2021; Accepted June 30, 2021

\begin{abstract}
The purpose of this research is to analyze what has been the effect that the time of the pandemic has generated in the Distribuidora Los Paisas, at the time of the recovery of the portfolios and also to determine the degree of operational and total leverage that it has, in other words, profitability will be analyzed as it is an extremely important variable in a company that is aimed at returning profit to its owner, taking into account that its presence shows growth and its absence will lead to failure of it. The study will focus on a descriptive, documentary and exploratory methodology, so the information will be obtained from the company for the period 2019 and the year 2020. Interpreting the indicators resulted in accounts receivable not providing sufficient liquidity with a negative effect, resulting in complications in meeting their obligations.
\end{abstract}

Receivables, Leverage, Financial indicators, Profitability

\section{Resumen}

El propósito de esta investigación es analizar cuál ha sido el efecto que ha generado el momento de la pandemia en la Distribuidora Los Paisas, al momento de la recuperación de las carteras y también determinar el grado de apalancamiento operativo y total que tiene. es decir, se analizará la rentabilidad por ser una variable de suma importancia en una empresa que tiene como objetivo devolver la ganancia a su propietario, teniendo en cuenta que su presencia muestra crecimiento y su ausencia conducirá al fracaso de la misma. El estudio se enfocará en una metodología descriptiva, documental y exploratoria, por lo que la información se obtendrá de la empresa para el período 2019 y el año 2020. La interpretación de los indicadores dio como resultado que las cuentas por cobrar no brinden suficiente liquidez con un efecto negativo, resultando en complicaciones. en el cumplimiento de sus obligaciones.

Cuentas por cobrar, Apalancamiento, Indicadores financieros, Rentabilidad

Citation: TUAREZ-SOLORZANO, Diana Elizabeth, TRIANA-JIMENEZ, Katherin Yessenia and GUTIERREZJARAMILLO, Daniel Néstor. Effect of the pandemic on the Distribuidora Los Paisas, through the study of leverage and activity. Journal of Administration and Finance. 2021. 8-22:1-8.

\footnotetext{
* Correspondence to Author (E-mail: dtuarez_est@utmachala.edu.ec)

$\dagger$ Researcher contributing first author.
} 


\section{Introduction}

The COVID-19 pandemic has become one of the most tragic humanitarian crises for Latin America and the world, with a negative impact on all economic sectors, so many of the businesses did not get the income they expected in the year. so it had a very dramatic impact on sales, thus on the company's profits.

Decision-making within a company is reflected in fast and optimal results, with the pandemic managers are unwilling to make losses, because sales are being made at low rates. one of the biggest concerns they have is the total closure of business and the increase in unemployment, therefore, they must develop a social economic plan that allows policies to help the company profit.

For all businesses or businesses, propaganda and advertising that are related to the circumstances of the pandemic is important. as real and potential customers are going to demand a lot of the products offered to them and give them the greatest assurance of being free from any contamination.

Because of this, companies take steps to help keep their business going and between them. it is meeting the needs of its clients, so the entrepreneurs chose to implement portfolio collection policies because this is one of the principal piles of the entity as it generates high levels of profitability. that is, they will try to keep existing customers and attract new customers, so they must grant credits and maintain inventories.

Accounts receivable are determined by the volume of sales to credit, this is effective because they set the due date of the invoice. Bearing the commitment of the clients for the service provided that the conditions of the mode of payment are becoming effective within the reasonable period (Umasi Olarte \& Choquepuma Olarte, 2016).

The importance of accounts receivable within any business represents benefits, so the degree of activity reason should be analyzed, which helps us determine backlog, high risk portfolios, and obtain timely and accurate reports. benefitting and obtaining utility from the company.
The management control tools used by most managers are the financial indicators in the same way leverage, because these instruments help to predict in the future the behavior of the company's economy, based on historical accounting information (Chávez \& Cordova, 2017)

The financial indicators of activity and leverage will be used, since by correctly interpreting them, they allow to measure the degree of solvency by predicting the capacity of effective indebtedness, helping to analyze the financial situation of companies to evaluate integral management and improve decisionmaking.

The objective of this research is to determine the degree of leverage and level of recovery of the portfolios of the Distribuidora Los Paisas by applying financial-activity indicators and operating leverage - total, which allows to determine the change in sales over the company's profit.

\section{Methodology}

Information was taken from the company dedicated to the distribution of bakery inputs from the period 2019 and 2020 to determine the degree of leverage and the movement that this economic entity has suffered in the time of global pandemic at the time of the recovery of portfolios performed a descriptive study, documentary and exploratory to demonstrate the effects that the pandemic has generated by applying financial indicators of activity ratio and operational and total leverages.

\section{Development}

\section{Financial indicators}

Financial indicators are considered as an indispensable tool for the proper financial management of companies, they are a reason that relate two or more variables taken from the financial statements, some resulting from relating accounts of the financial statements and others of the statement of results, the indicators have more value when compared to previous periods so that you can determine the degree of difference they have had. Some of the indicators are represented in percentages and others in numbers of times (Correa García, Gómez Restrepo, \& Londoño Castañeda, 2018).

TUAREZ-SOLORZANO, Diana Elizabeth, TRIANAJIMENEZ, Katherin Yessenia and GUTIERREZ-JARAMILLO, Daniel Néstor. Effect of the pandemic on the Distribuidora Los Paisas, through the study of leverage and activity. Journal of Administration and Finance. 2021 
The financial indicators in the business field are essential to know if the company can fulfill its obligations in the long or short term, by making a financial diagnosis allowing to know the current situation, In the profitability and verifying the fulfillment of the clients in the payment of the portfolios (Herrera Freire, Herrera Freire, Vega Rodriguez, \& Vivanco Granda, 2016).

By analyzing financial indicators such as liquidity, solvency, profitability and efficiency, these will help the people in charge of the administration of an economic entity make a good decision in the administrative and financial part. Seeking strategies that will enable them to achieve the goals in one way or another (Garzozi Pincay, Perero Triguero, Rangel Luzuriaga, \& Vera Alcivar, 2017).

An organization that performs cost application effectively and efficiently will serve as a contribution tool for growth ranging from production to admiration achieving goals based on administrative and operational strategies for stability and profitability. Generating a positive impact on the economic entity (Correa Mejia, Martinez Molina, Ruiz Criollo, \& Yepes Montoya, 2018).

\section{Activity indicators}

The activity indicators that you understand for this reason allow us to assess how quickly inventories become cash they measure the speed with which the company operates in the management of inventories, collections and expenses. it also evaluates the efficiency with which assets are used. These reasons explain why companies are able to rotate faster than other assets (Ollague Valarezo, Ramón Ramón, Soto Gonzalez, \& Novillo, 2017).

These indicators are also known as rotation indicators, which require measuring the efficiency with which a company uses its assets, depending on the speed of recovery of the values applied in them (Espinoza, Figueroa, Lainez, \& Malave, 2017). following:

\section{Inventory turnover}

This indicator allows you to measure the liquidity that inventory has in the business, a comparison is made to see what the difference was with the previous year. If the inventory rotation shows the very low times of inventory rotation, it makes any strategy difficult because it involves having to invest working capital in inventory management (Cardona Olaya, Martínez Carvajal, Velásquez Retrepo , \& López Fernández , 2015).

The following formula applies:

Inventory rotation $=\frac{\text { Net sales }}{\text { Average inventory }}$

\section{Average inventory period}

Measures the number of days in the year the inventory is renewed, but this indicator, while rotating at least four times a year, its analysis by purchase group overlaps the results for each product. Thus, the possible deficiencies in their availability or in their sales levels are hidden (Villar Ledo \& Ledo Ferrer, 2016).

Formula to apply this indicator:

Average inventory period $=\frac{360}{\text { Inventory rotation }}$

\section{Fixed asset turnover}

This indicator sets the productivity of fixed asset use, i.e., shows the volume of sales obtained for each dollar of net fixed assets (Sánchez Giner, García Regalado, \& Holguín Alvarado, 2019).

The following formula applies:

Fixed asset rotation $=\frac{\text { Current net sales }}{\text { Net fixed asset }}$

\section{Account turnover}

This indicator represents the number of times credit sales have been generated and cash portfolio has been recovered over the period (Flores Morales \& Naval Carrasco, 2017). The following formula applies:

Turnover of accounts receivable $=\frac{\text { Annual sales on credit }}{\text { accounts receivable. }}$ 


\section{Average accounts receivable lead time}

Indicates the number of days accounts receivable take to become cash. When there is a higher number of delinquencies in the accounts receivable, that is to say that it does not have sufficient flow of resources to respond to its short-term obligations, while its liquidity is concentrated in the accounts receivable (Cárdenas \& Velasco, 2014). The following formula applies:

Average Term of Accounts Receivable to Customer $=\frac{360}{\text { Receivables Rotation }}$

\section{Leverage}

All businesses need to leverage to maximize profitability because it is considered one of the main factors influencing risk and business fragility. While large businesses are less likely to fail, small businesses are more likely to borrow in the short term. (Salome, Salazar \& Lasso Palacios, 2020).

Leverage analysis helps determine the effect it has on profitability and financial position of businesses, and analyzes factors of indebtedness, repayment capacity, cash applications and others, failure to do so could have significant negative effects (Salcedo lasado \& Piza Pelay, 2018).

Leverage compares financing originating from third parties as shareholder resources, thus contributing to a small part of the total financing, the risks of the company fall on creditors (Fontalvo Herrera, de la Hoz Granadillo, \& Vergara, 2012).

Within leverage are: Operational, financial and total.

\section{Operating leverage}

is the leverage effect on the company's results reflected in fixed costs, i.e., operating leverage is the discrimination against costs by classifying it between fixed and variable costs? Because they are information only managed by people working in the entity, that is, they are not information that is stated in the annual declarations that are in public law (Diéguez Soto \& Aranda, 2006). leverage:

The following formula applies in this
$\boldsymbol{G A O}=\frac{(V T-C V T)}{(V T-C V T-C F)}$

Where:

VT: Total sale

CVT: Total variable cost

CF: Fixed cost

\section{Financial leverage}

Financial leverage is defined as a tool used by companies to look for higher equity investments plus debt aimed at higher profitability, i.e., supporting organizations based on their accounting actions (Marin, 2019).

The effect of financial leverage has three paths: Positive, negative, and neutral, when positive, economic benefits have to be higher than the financial costs generated by debt. When negative economic benefits are lower than the financial costs generated by debt, as neutral we will have that economic benefits are equal to the financial costs generated by debt (Salcedo Lasado \& Piza Pelay, 2018).

The following formula applies:

$\boldsymbol{U P A}=\frac{(U O-I)(1-P P T) *(1-P I)-(D P)}{N A P}$

Where:

UO: Operational Utility

I: Interest

PPT: Percentage of Worker Participation

PI: Percentage of Taxes

DP: Preferred Dividends

NAP: Number of Shares Paid
TUAREZ-SOLORZANO, Diana Elizabeth, TRIANAJIMENEZ, Katherin Yessenia and GUTIERREZ-JARAMILLO, Daniel Néstor. Effect of the pandemic on the Distribuidora Los Paisas, through the study of leverage and activity. Journal of Administration and Finance. 2021 


\section{Total leverage}

Total leverage is intended to measure the percentage change in earnings per share because of sales changes, this leverage is a combination of operating and financial leverage, is also the result of using fixed cost assets or funds, therefore, it is seen as the total impact of fixed costs on the company's operational and financial structure (Castañeda Vélez \& Ortega Ortega Ortega, 2019).

The following formula applies:

$$
\boldsymbol{G A T}=\frac{(V T-C V T)}{(V T-C V T-C F-I)}
$$

Where:

VT: Total sale

CVT: Total variable cost

CF: Fixed cost

I: Interest

\section{Result}

The case of the Distribuidora Los Paisas dedicated to the distribution of bakery inputs from the period 2019 and 2020 is developed to determine the reason of activity and the degree of leverage.

\begin{tabular}{|l|r|r|}
\hline \multicolumn{2}{|c|}{ Dates } \\
\hline Net Sales & \multicolumn{1}{|c|}{$\mathbf{2 0 1 9}$} & $\mathbf{2 0 2 0}$ \\
\hline Annual Sales on credit & $22.221,38$ & $333.571,29$ \\
\hline Avoic & $56.566,27$ & $32.992,83$ \\
\hline A net fixed asset & $9.635,71$ & $11.326,29$ \\
\hline $\begin{array}{l}\text { Promedium of customer } \\
\text { accounts }\end{array}$ & $10.767,67$ & $25.606,49$ \\
\hline
\end{tabular}

Table 1 Data for calculation of the activity rate Source: Statement of Result, Financial Statement for the Year 2019 and 2020

\section{Inventory rotation}

Year 2019

Inventory rotation $=\frac{481.221,38}{56.566,27}$

Inventory rotation $=8,50$
Year 2019

Inventory rotation $=\frac{333.571,29}{53.465,29}$

Inventory rotation $=6,24$

The company has an inventory turnover in the period 2020 of 6.24 times, and in the year 2019 rotates 8.50 times it is evident that the result is not favorable because it is not recovering its income or profits faster from the company.

\section{Average inventory period}

Year 2019

Average inventory period $=\frac{360}{8,50}$

Average inventory period $=42,35$

Year 2020

Average inventory period $=\frac{360}{6,24}$

Average inventory period $=57,69$

The company changed inventory in the year 202057.69 days and in the year 2019 reached about 42.35 days, i.e. the company in the year 2020 had more units in the warehouse for more days having an idle capacity that generates no profit

Fixed asset rotation

Year 2019

Fixed asset turnover $=\frac{481.221,38}{9.635,71}$

Fixed asset turnover $=49,94$

Year 2020

Fixed asset rotation $=\frac{333.571,29}{11.326,34}$

Fixed asset rotation $=29,45$

The company has a fixed asset turnover in the year 2019 is performed 49.94 times, whereas in the year 2020 it is realized 29.45 there being a decrease that in the year 2020 the fixed asset was able to cover less sales than the previous year.

TUAREZ-SOLORZANO, Diana Elizabeth, TRIANAJIMENEZ, Katherin Yessenia and GUTIERREZ-JARAMILLO, Daniel Néstor. Effect of the pandemic on the Distribuidora Los Paisas, through the study of leverage and activity. Journal of Administration and Finance. 2021 


\section{Turnover of accounts receivable}

Year 2019

Turnover of accounts receivable $=\frac{22.220,15}{10.767,67}$

Turnover of accounts receivable $=2,06$

Year 2020

Turnover of accounts receivable $=\frac{32.992,83}{25.606,49}$

Turnover of accounts receivable $=1,28$

The company in the period 2020 recovers the portfolio 1.28 times, comparing with the result of the period 2019 which was 2.06 times, meaning that in the year 2020 there is a decrease in inventory turnover. and the terms of the credit policy state that the portfolio recovery is 30 days, that it must be 12 times in the year, as it covers less times that there is inefficiency or mismanagement in the sales.

\section{Average term of accounts receivable to customers}

Year 2019

Average term of accounts receivable to customers $=\frac{360}{2,06}$

Average term of accounts receivable to customers $=174,75$

Year 2020

Average term of accounts receivable to customers $=\frac{360}{1,28}$

Average term of accounts receivable to customers $=281,25$

The company in 2020 delays in collecting its clients on credit 281.21 days while in 2019 it takes 174.75 days, i.e., there is an increase in the collection of accounts receivable in 2020 .

\begin{tabular}{|c|c|c|}
\hline \multicolumn{3}{|c|}{ Dates } \\
\hline & 2019 & 2020 \\
\hline Total Sales & $481.221,38$ & $333.571,29$ \\
\hline A total variable cost & $425.764,04$ & $296.798,14$ \\
\hline Fixed cost & $12.989,76$ & $7.325,89$ \\
\hline Interests & 14.436 .34 & $5.445,28$ \\
\hline
\end{tabular}

Table 2 Leverage calculation data

Source: Statement of Result, Financial Statement for 2019 and 2020

\section{Operational leverage}

Year 2019

$\boldsymbol{G A O}=\frac{(481.221,38-425.764,04)}{(481.221,38-425.764,04-12.989,76)}$

$\boldsymbol{G A O}=1,31$

Year 2020

$\boldsymbol{G A \boldsymbol { O }}=\frac{(333.571,29-296.798,14)}{(333.571,29-296.798,14-7.325,89)}$

$\boldsymbol{G A O}=1,24$

The company in 2020 can increase its operating profit by 1.24 per $1 \%$ that it is able to increase its level of operations, there being a decrease in contrast to the year 2019 that was obtained from 1.31.

Total Leverage

Year 2019

$\boldsymbol{G A T}=\frac{(481.221,38-425.764,04)}{(481.221,38-425.764,04-12.989,76-14.436 .34)}$

$\boldsymbol{G A T}=1,98$

Year 2020

$\boldsymbol{G A T}=\frac{(333.571,29-296.798,14)}{(333.571,29-296.798,14-7.325,89-5.445,28)}$

$\boldsymbol{G A T}=1,53$

The company obtained a GAT of 1.53 in 2020 and a GAT of 1.98 in 2019, indicating that the impact of the change in sales was higher in 2019 and decreased in 2020. their risk and increased profits, due to the direct relationship maintained by the degree of total leverage, risk, and utility.

\section{Conclusion}

The company dedicated to the distribution of bakery inputs was affected by the pandemic in terms of the recovery of the portfolio obtained a rotation in 2020 of 281.21 days while in 2019 it was 174.75 days. 
That is, in 2020, it took longer to recover the portfolio, which is negative because I raise money longer and made it difficult to meet its suppliers, which means that the accounts receivable did not give enough liquidity, and inventory turnover was also affected in 2020 as it broken only 6.24 times compared to 2019 which was 8.50 , i.e., not favorable because it is not getting faster income.

In terms of leverage in GAO and GAT year 2020, there was a decrease compared to the previous year, leading to a decrease in risk and thus a lower profit, i.e., there was less income, this was due to the pandemic that severely affected the company's sales.

\section{References}

Apaza Zuta , E. S., Salazar Salome, E. O., \& Lazo Palacios , M. A. (03 de Marzo de 2020). Apalancamiento y rentabilidad: caso de estudio en una empresa textil peruana. 6(1), 9-16. doi:https://doi.org/10.17162/rivc.v6i1.1253

Cárdenas , M., \& Velasco , B. (2014). Incidencia de la morosidad de las cuentas por cobrar en la rentabilidad y la liquidez: estudio de caso de una Empresa Social del Estado prestadora de servicios de salud. Revista Facultad Nacional de Salud Publica, 32(1). Obtained from: https://revistas.udea.edu.co/index.php/fnsp/artic le/view/15182/15743

Cardona Olaya , J. L., Martínez Carvajal, A., Velásquez Retrepo , S. M., \& López Fernández , Y. M. (22 de Diciembre de 2015). Análisis de indicadores financieros del sector manufacturero del cuero y marroquinería: un estudio sobre las empresas colombianas. Informador Técnico , 79(2).

doi:https://doi.org/10.23850/22565035.160

Castañeda Vélez, F. L., \& Ortega Ortega, A. C. (Diciembre de 2019). Cuentas por cobrar y su efecto en el apalancamiento en empresas que comercializan equipos de seguridad. Revista Observatorio de la Economía Latinoamericana. Obtained from: https://www.eumed.net/rev/oel/2019/12/empres as-equipos-seguridad.html
Chávez , N., \& Córdova, C. (2017). medición del riesgo de la gestión financiera de las compañías con la utilización del análisi discriminante: el caso de las industrias de la región 7 del Ecuador. Revista Publicando , 4(13), 90-107. Obtained from:

https://core.ac.uk/download/pdf/236644363.pdf

Correa García , J. A., Gómez Restrepo , S., \& Londoño Castañeda, F. (Diciembre de 2018). Indicadores financieros y su eficiencia en la explicación de la generación de valor en el sector cooperativo. Revista Facultad De Ciencias Económicas, 26(2), 129-144. doi:https://doi.org/10.18359/rfce.3859

Correa Mejia, D., Martinez Molina, L., Ruiz Criollo, M., \& Yepes Montoya, M. (2018). Los indicadores de costos: una herramienta para gestionar la generación de valor en las empresas industriales colombianas. Journal of MAnagement and Economics for Iberoamerica, 34(147), 190-199. doi:https://doi.org/10.18046/j.estger.2018.147.2 643

Diéguez Soto, J., \& Aranda, E. (2006). Un análisis del apalancamiento operativo y su relación con el resultado empresarial. Revista iberoamericana de contabilidad de gestión , 4(7), 47-80. Obtained from: http://www.observatorio-

iberoamericano.org/RICG/N__/Julio\%20Diegu ez\%20y\%20Eva\%20Aranda.pdf

Espinoza , J., Figueroa, I., Lainez, A., \& Malave, L. (4 de Septiembre de 2017). Rentabilidad financiera del sector camaronero: Formulación del árbol de decisión mediante el algoritmo de Chaid. Revista de Negocios y PyMes, 3(9), $27-$ 34. Obtained from: https://www.ecorfan.org/spain/researchjournals/ Negocios_y_PyMES/vol3num9/Revista_de_Ne gocios_\&_PYMES_V3_N9.pdf\#page $=8$

Flores Morales , M. K., \& Naval Carrasco, Y. (Enero-Junio de 2017). Gestión de cuentas por cobrar y la rentabilidad de las empresas del sector industrial que cotizan en la bolsa de Valores de Lima, períodos 2010 al 2014. Revista de Investigación Universitaria , 6(1). doi::https://doi.org/10.17162/riu.v6i1.1039 
Fontalvo Herrera, T., De la Hoz Granadillo , E., \& Vergara, J. C. (2012). Aplicación de análisi discriminante para evaluar el mejoramiento de los indicadores financieros en las empresas del sector alimento de Barranquilla-Colombia. Ingeniare. Revista chilena de ingeniería, 20(3), 320-330. doi:http://dx.doi.org/10.4067/S0718 33052012000300006

Garzozi Pincay, R., Perero Triguero, J., Rangel Luzuriaga, E., \& Vera Alcivar, J. (2017). Análisis de los indicadores financieros de los principales bancos privados del Ecuador. Revista de Negocios / PyMES, 3(9), 1-16. Obtained from:

https://www.ecorfan.org/spain/researchjournals/ Negocios_y_PyMES/vol3num9/Revista_de_Ne gocios_\&_PYMES_V3_N9.pdf\#page=8

Herrera Freire, A. G., Herrera Freire , A. H., Vega Rodriguez, S. R., \& Vivanco Granda, E. C. (Mayo de 2016). Razones financieras de liquidez en la gestion empresarial para toma de decisiones. Revista de la facultad de Ciencias Contables, 24(46), 151-160. Obtained from: https://d1wqtxts1xzle7.cloudfront.net/56665440 /13249-45984-1-

PB_1.pdf?1527435715=\&response-contentdisposition=inline\%3B+filename\%3DPB_1.pdf $\&$ Expires $=1614096134 \&$ Signature $=O Q W 14$ Iup y1GXQQkANcNoCF9Ox-

Sz9BzbA4hoy zx5d4sn5j8nx1LBvCqIuOjE3n kPdErrGuNGp8MmvJEIhnGa

Marin, L. E. (Marzo de 2019). Gestión estratégica para el apalancamiento de la contabilidad de costos en organizaciones empresariales. Revista Observatorio de la Economía Latinoamericana. Obtained from: https://www.eumed.net/rev/oel/2019/03/contabi lidad-costos-empresariales.html

Ollague Valarezo, K. J., Ramón Ramón, D. I., Soto Gonzalez, C. O., \& Novillo, E. F. (11 de Septiembre de 2017). Indicadores financieros de gestión: análisis e interpretación desde una visión retrospectiva y prospectiva. INNOVA Research Journal , 2(8.1), 22-41. doi:https://doi.org/10.33890/innova.v2.n8.1.201 7.328
Salcedo Lascado , R., \& Piza Pelay , P. P. (2018). Apalancamiento financiero y su incidencia en la rentabilidad. Revista Observatorio de la Economia Latinoamericana. Obtained from: https://www.eumed.net/rev/oel/2018/11/apalanc amiento-financiero-rentabilidad.html

Sánchez Giler , S., García Regalado, J., \& Holguín Alvarado, W. (2019). Industria ecuatoriana de elaboración de productos alimenticios: Análisis econométrico de indicadores de rentabilidad, período 2010-2017. Revista Espacios, 40(1), 27. Obtained from: http://www.revistaespacios.com/a19v40n01/a19 v40n01p27.pdf

Umasi Olarte, B., \& Choquepuma Olarte, V. (2016). Tendencia de las cuentas por cobrar y ratios de actividad en la empresa Alpe Corporacion S.A. en los periodos 2011-2015. Revista de Investigacion Universitaria, 5(2). doi: https://doi.org/10.17162/riu.v5i2.978

Villar Ledo, L., \& Ledo Ferrer, M. C. (MayoAgosto de 2016). Aplicación de herramientas estadísticas para el análisis de indicadores. Ingenieria Industrial , 37(2), 138-150. Obtained from:

http://scielo.sld.cu/pdf/rii/v37n2/rii04216.pdf 